\title{
PENGARUH PUPUK ORGANIK CAIR SIRIH DAN GAMAL (SIRGAM PLUS) TERHADAP PERTUMBUHAN DAN PRODUKSI TANAMAN TERUNG UNGU (Solanum melongena $L$.)
}

\section{The Effect of Betel and Gamal Liquid Organic Fertilizer on The Growth and Production of Purple Eggplant (Solanum melongena L.)}

\author{
Nur Aisyah, Dahlan, Abd. Azis H., dan Rachmat* \\ Politeknik Pembangunan Pertanian Gowa \\ *e-mail: sumarmanrachmat@gmail.com
}

Received: 7 September 2021; Accepted: 28 November 2021; Published: 25 Desember 2021

\begin{abstract}
ABSTRAK
Pupuk organik cair adalah larutan yang berasal dari sisa pembusukan bahan-bahan organik yang berasal dari sisa tanaman, kotoran hewan yang kandungan unsur haranya lebih dari satu unsur. Tujuan dari kaji widya ini adalah untuk mengetahui pengaruh aplikasi pupuk organik cair sirih dan gamal terhadap pertumbuhan dan produksi tanaman terung ungu (Solanum melongena L.). Metode kajian ini dilaksanakan di lahan Anggota Kelompok Tani Borong, Kelurahan Romang Lompoa, Kacamatan Bontomarannu, Kabupaten Gowa pada bulan Maret sampai Juni 2021. Kajian dilaksanakan dengan menggunakan Rancangan Acak Kelompok (RAK) yang terdiri dari 4 perlakuan dan 3 ulangan, sehingga didapatkan 12 jumlah plot perlakuan yaitu $\mathrm{P}_{0}$ (tanpa pemberian/kontrol), $\mathrm{P}_{1}(0,2$ 1/Ha $/ 300 \mathrm{ml} /$ Liter air/petak $), \mathrm{P}_{2}(0,4$ 1/Ha / $600 \mathrm{~m} /$ Liter air/petak) dan $\mathrm{P}_{3}$ (6 1/Ha setara dengan $900 \mathrm{ml} /$ Liter air/petak). Hasil kaji widya menunjukkan bahwa: Respons petani pada aplikasi pupuk organik cair sirih dan gamal terhadap pertumbuhan dan produksi tanaman terung ungu (Solanum melongena L) terbaik adalah perlakuan (P3) dengan dosis 900 $\mathrm{ml} /$ Liter air/petak.
\end{abstract}

Kata kunci: Sirih, gamal, pupuk organik cair, terung ungu

\section{ABSTRACT}

Liquid organic fertilizer is a solution that comes from the residue of the decaying of organic materials made from plant residues, animal dung that contain more than one nutrient element. The purpose was to determine the production of betel and Gamal liquid organic fertilizer on the growth and production of purple eggplant (Solanum melongena L.) This study method was conducted on Borong Farmer Group Members, Romang Lompoa Village, Bontomarannu subdistric, Gowa Regency from March to June 2021. The study was conducted using a Randomized Block Design consisting of 4 treatments and 3 repeatation, so that 12 treatment plots were obtained, namely PO (without administration/control), P1 (0.2 l/ha/300 $\mathrm{ml} /$ liter of water/plot). ), P2 (0.4 l/Ha $/ 600 \mathrm{~m} /$ Liter of water/plot) and P3 (6 l/Ha is equivalent to 900 $\mathrm{ml} /$ Liter of water/plot). The results of this kajiwidya's showed that: The response of farmers to the application of liquid organic fertilizer produced from betel and Gamal to the growth and production of purple eggplant (Solanum melongena L) was the best treatment (P3) with a dose of $900 \mathrm{ml} / \mathrm{liter}$ of water/field.

Keywords: Betel and gamal, liquid organic fertilizer, purple eggplant

\section{PENDAHULUAN}

Pertanian merupakan salah satu sektor paling penting dalam kemajuan ekonomi masyarakat di indonesia. Sektor pertanian selama ini dikenal sebagai satu-satunya sektor ekonomi

Diterbitkan Oleh,

Unit Penelitian dan Pengabdian Masyarakat, Politeknik Pembangunan Pertanian Gowa

http://ejournal.polbangtan-gowa.ac.id yang paling bertahan dari berbagai gejolak dan krisis. Era modern ini, banyak sekali bermunculan jenis komoditi baru yang bisa dibudidayakan, salah satunya adalah budidaya terung ungu yang memiliki prospektif dipasaran. 
Produk hortikultura ini setiap hari selalu dibutuhkan masyarakat dan menjadi bagian penting dari usaha peningkatan produksi pertanian yang bermanfaat sebagai sumber gizi dalam menunjang kesehatan masyarakat dan meningkatkan pendapatan masyarakat khususnya bagi para petani (Karim Fahri $d k k$, 2013).

Terung ungu (Solanum melongena L.) adalah tanaman hortikultura yang ditanam untuk dimanfaatkan buahnya dan menjadi salah satu bahan pangan yang mudah didapat dan murah harganya. Terung mengandung gizi yang cukup tinggi, terutama kandungan vitamin A, Bkompleks, Fosfor, thiamin, pyridoxine, riboflavin, zat besi, phosphorus, manganese potasium. Buah terung juga mengandung serat yang tinggi sehingga bagus untuk pencernaan. Terung juga diketahui bagus untuk kesehatan jantung, menekan kolestrol dan diabetes. (Sahid dkk, 2014).

Kelurahan Romang Lompoa Kecamatan Bontomarannu Kabupaten Gowa, merupakan salah satu kelurahan dimana profesi penduduknya sebagian besar adalah petani. Banyak jenis tanaman yang dibudidayakan oleh masyarakat Romang Lompoa, baik tanaman pangan maupun hortikultura, salah satunya adalah tanaman terung ungu. Namun ketergantungan kepada input kimiawi mengakibatkan biaya produksi terung ungu menjadi tinggi, sementara itu hasil pertanian tetap bahkan cenderung mengalami penurunan, sehingga mengakibatkan pendapatan petani menjadi rendah. Untuk mendapatkan potensi hasil terung ungu yang diharapkan dapat dilakukan penggunaan pupuk yang ramah lingkungan.

Berdasarkan hasil identifikasi potensi wilayah di Kelurahan Romang Lompoa, Kecamatan Bontomarannu, diketahui bahwa tanaman sirih dan tanaman gamal banyak sekali tumbuh di daerah tersebut. Hampir setiap pekarangan rumah memiliki tanaman sirih yang kurang dimanfaatkan masyarakat. Padahal tanaman Sirih dapat dimanfaatkan sebagai bahan organik karena mengandung unsur $1,12 \% \mathrm{~N}$, $0,5 \% \mathrm{P}, 0,51 \% \mathrm{~K}, 2,15 \% \mathrm{C}$ - Organik, dan 3,70\% Bahan Organik yang cukup tinggi sehingga dapat meningkatkan $\mathrm{pH}$ tanah serta kaya akan kandungan minyak atsiri yang sekaligus dapat melindungi tanaman dari serangan hama. Sama halnya dengan tanaman gamal yang hanya dijadikan sebagai tanaman pagar, juga dapat dimanfaatkan sebagai bahan organik karena memiliki kandungan hara yang tinggi yaitu memiliki unsur 3-6\% N, 0-31\% P; 0,77\% K; 15$30 \%$ serat kasar. Gamal juga mempunyai kandungan nitrogen yang cukup tinggi dengan $\mathrm{C} / \mathrm{N}$ rendah, menyebabkan biomassa tanaman ini mudah mengalami dekomposisi (Jusuf, dkk 2007).

Berdasarkan penelitian yang dilakukan oleh Melda Pratiwi (2017) pemberian komposisi bahan organik pada pupuk cair $250 \mathrm{~g}$ daun sirih hijau + $50 \mathrm{~mL}$ larutan EM-4 + $50 \mathrm{~mL}$ larutan gula merah dan $900 \mathrm{~mL}$ air mampu mengoptimalkan pertumbuhan dan hasil pada tanaman tomat. Sedangkan penelitian (Busroni, dkk 2018) menunjukkan bahwa Pemberian MOL daun gamal pada perlakuan $20 \%$ menunjukkan hasil yang baik yaitu berat buah per tanaman rata-rata sebesar 219,03 g dan berat buah per petak ratarata sebesar 4027,75 g

Peneliti tertarik menggunakan bahanbahan tersebut dalam kaji widya ini karena bahan-bahan tersebut mudah didapatkan dan kurang dimanfaatkan secara maksimal oleh petani padahal dari bahan tersebut dapat menyediakan unsur hara seperti $\mathrm{N}, \mathrm{P}$, dan $\mathrm{K}$ bagi pertumbuhan tanaman terung ungu melalui proses fermentasi. Sehingga dapat meningkatkan pendapatan petani sekaligus memperbaiki kualitas lingkungan. Berdasarkan latar belakang di atas maka penulis melakukan kaji widya tentang Respons Petani Pada Aplikasi Pupuk Organik Cair Sirih Dan Gamal (Sirgam Plus) Terhadap Pertumbuhan Dan Produksi Tanaman Terung Ungu (Solanum melongena L).

\section{METODE PENELITIAN}

\section{Tempat dan Waktu}

Kaji widya dilaksanakan di Kelurahan Romang Lompoa, Kecamatan Bontomarannu, Kabupaten Gowa, berlangsung pada bulan April sampai bulan Juli 2021. Kegiatan penyuluhan dilaksanakan di kelompok tani Borong Kelurahan Romang Lompoa, Kecamatan Bontomarannu, Kabupaten Gowa, Provinsi Sulawesi Selatan.

\section{Bahan dan Alat}

Alat yang digunakan dalam kaji widya ini adalah cangkul, gembor, meteran, botol plastik, gelas ukur, ember besar, mistar, timbangan, saringan, penumbuk, pengaduk, media semai, alat tulis dan kamera. 
Bahan yang digunakan dalam kegiatan kaji widya yaitu : Benih Terung Ungu varietas Yufita F1, $3 \mathrm{~kg}$ daun sirih, $3 \mathrm{~kg}$ daun gamal, 6 liter air cucian beras, $1 \mathrm{~kg}$ gula merah, $200 \mathrm{~mL}$ Bioaktivator. Sedangkan yang digunakan dalam penyuluhan yaitu kuesioner dan folder/materi penyuluhan.

\section{Metode Pelaksanaan}

Aplikasi pupuk organik cair Pupuk Organik Cair Sirgam Plus Terhadap Pertumbuhan Dan Produksi Tanaman Terung Ungu (Solanum melongena L) dilaksanakan dengan menggunakan metode Rancangan Acak Kelompok (RAK) dengan empat perlakuan dan tiga ulangan yaitu sebagai berikut:

P0 : Tanpa perlakuan (kontrol)

P1 : Pemberian POC 0,2 L/Ha setara dengan $300 \mathrm{~mL} /$ liter air/petak

P2 : Pemberian POC 0,4 L/Ha setara dengan $600 \mathrm{~mL} /$ liter air/petak

P3 : Pemberian POC 0.6 L/Ha setara dengan $900 \mathrm{~mL} / \mathrm{liter}$ air/petak

\section{Parameter Pengamatan} berikut:

Parameter yang diamati adalah sebagai

1. Tinggi Tanaman $(\mathrm{cm})$

Diukur dari pangkal batang diatas permukaan tanah sampai titik tumbuh tanaman. Pengukuran dilakukan mulai pada umur 14, 21, 28, dan 35 (HST).

2. Jumlah Daun (helai)

Diamati dengan menghitung jumlah daun yang telah terbuka sempurna. Pengamatan dilakukan sebanyak 4 kali mulai pada umur 14 , 21, 28, dan 35 (HST).

3. Jumlah Cabang (buah)

Jumlah cabang diamati dengan menghitung jumlah cabang yang muncul dari batang utama. Pengamatan dilakukan pada saat cabang pertama muncul yaitu 28 HST dan 35 HST, sebanyak 4 sampel per petak.

4. Berat Basah $(\mathrm{g})$

Diamati dengan cara menimbang berat buah segar per tanaman pada saat panen. Sebanyak 4 tanaman sampel per petak.

\section{Analisis Data}

Data dari hasil kaji widya akan diolah dengan menggunakan rumus uji F (Sastrosupadi, 2000) sebagai berikut:
Keterangan:

$$
Y_{i j}=\mu+T i+B_{j}+\epsilon_{i j}
$$

$\mathrm{Y}_{\mathrm{ij}}=$ Respons atau nilai pengamatan dari perlakuan ke-i dan ulangan ke-j.

$\mu=$ Nilai tengah umum

$\mathrm{T}_{\mathrm{i}}=$ Pengaruh perlakuan ke-i

$\mathrm{B}_{\mathrm{j}}=$ Pengaruh blok ke- $\mathrm{j}$

$\epsilon_{\mathrm{ij}}=$ Pengaruh galat percobaan dari perlakuan ke-i dan ulangan ke-j

Data dari hasil pengukuran dan pengamatan selanjutnya Uji beda nyata terkecil (BNT) dilakukan apabila pada sidik ragam (anova) rancangan menunjukan uji $\mathrm{F}$ berbeda nyata $(5 \%)$ atau sangat nyata $(1 \%)$.

\section{Pelaksanaan Kajian}

1. Persiapan lahan

Persiapan lahan meliputi proses pengolahan lahan, pembuatan bedengan dan pemupukan dasar menggunakan kapur 1 $\mathrm{kg} /$ bedengan dan pupuk kandang 1.5 $\mathrm{kg} /$ bedengan. Lahan dibersihkan dari gulma atau rumput-rumputan dan kotoran lainnya.

\section{Penyemaian benih}

Persemaian benih terung dilakukan pada media semai dengan ukuran panjang $150 \mathrm{~cm}$ dan lebar $50 \mathrm{~cm}$ serta diberi naungan. Media semai dicampur dengan pupuk kandang kotoran sapi untuk nutrisi benih selama persemaian. Benih terung sebelum disemai direndam dengan air kemudian benih diperam pada kain basah selama satu hari. Media semai disiram kemudian benih disebar pada bedengan secara merata. Media semai selanjutnya ditutup dengan daun pisang. Penutup semaian dibuka pada saat benih mulai tumbuh. Persemaian disiram setiap pagi dan sore hari.

3. Penanaman

Penanaman atau pindah tanam bibit ke petakan/bedengan dilakukan pada sore hari dan bibit telah berumur 3 minggu setelah semai. Bibit yang digunakan adalah bibit yang sehat dan tidak cacat. Penanaman dilakukan dengan jarak tanam $70 \mathrm{~cm} \times 60 \mathrm{~cm}$ dan setiap lubang tanam diisi dengan satu bibit. Lubang tanam kemudian ditutup dan dipadatkan dengan tanah disekitar tanaman kemudian disiram. Pada 1 plot percobaan terdapat 6 tanaman dan total populasi pada 12 plot yaitu sebanyak 72 tanaman. Sampel yang diambil adalah 4 tanaman setiap plot sehingga terdapat 48 sampel untuk semua plot percobaan. 
4. Pemeliharaan meliputi:

Pemeliharaan pada tanaman terung

a. Penyiraman

Penyiraman dilakukan setiap hari yaitu pagi dan sore hari. Penyiraman tidak perlu dilakukan apabila turun hujan, namun apabila cuaca kering makapenyiraman dapat dilakukan lebih sering agar tanaman tidak layu dan kekeringan.

b. Penyulaman

Penyulaman dilakukan apabila terdapat tanaman yang tidak tumbuh atau mati pada saat setelah pindah tanam. Penyulaman paling lambat dilakukan satu minggu setelah pindah tanam.

c. Aplikasi pupuk organik cair Sirgam Plus

Pupuk organik cair Sirgam Plus diaplikasikan ketanaman dengan cara disiram pada tanaman dan tanah disekitar tanaman. Pengaplikasian pupuk organik cair Sirgam Plus dilakukan pada pagi hari saat tanaman berumur 7 , 14, 21, dan 28 hari setelah pindah tanam dengan konsentrasi sesuai rancangan perlakuan.

d. Pengendalian gulma

Pengendalian gulma dilakukan sesuai kondisi gulma untuk menghindari persaingan dalam pengambilan unsur hara didalam tanah. Pengendalian gulma dilakukan dengan cara manual yaitu mencabut gulma yang tumbuh pada bedengan.

\section{e. Pengendalian hama dan penyakit}

Karena pupuk organik cair Sirgam Plus merupakan pupuk yang tidak hanya bermanfaat untuk memberi unsur hara pada tanaman tetapi juga sebagai pestisida bagi tanaman terung ungu, jadi hama dan penyakit otomatis akan dikendalikan melalui pemberian pupuk organik cair Sirgam Plus. Selain itu dapat pula dikendalikan dengan cara manual yaitu mencabut dan membuang tanaman yang terserang penyakit. 5. Panen

Tanaman terung berbuah pada umur tanaman 55 hari sampai 75 hari setelah pindah tanam atau umur 12 hari sampai 15 hari sejak bunga mekar. Ciri buah kelihatan segar, warna buah mengkilat, daun dan masih muda. Cara panen yaitu dengan memetik langsung buah menggunakan gunting potong.

\section{HASIL DAN PEMBAHASAN}

\section{Tinggi Tanaman}

Hasil pengamatan pada aplikasi pupuk organik cair sirih dan gamal (Sirgam Plus) terhadap pertumbuhan dan produksi tanaman terung ungu yang telah dilaksanakan dengan parameter pengamatan yaitu tinggi tanaman, yang dilakukan pada umur 14 sampai 35 HST, dapat di lihat pada tabel 1 .

Tabel 1. Tinggi tanaman terung ungu pada aplikasi pupuk organik cair (Sirgam Plus) pada umur 14, 21, 28,35 HST

\begin{tabular}{ccccc}
\hline \multirow{2}{*}{ Perlakuan } & \multicolumn{4}{c}{ Minggu $(\mathrm{cm})$} \\
\cline { 2 - 5 } & 14 HST & 21 HST & 28 HST & 35 HST \\
\hline P0 & $9,50^{\text {a }}$ & 16,90 & 24,49 & 54,49 \\
P1 & $13,74^{\text {ab }}$ & 25,85 & 34,66 & 68,81 \\
P2 & $14,69^{\mathrm{bc}}$ & 23,61 & 32,85 & 65,14 \\
P3 & $19,07^{\mathrm{d}}$ & 28,28 & 37,05 & 73,20 \\
BNT & 4,33 & tn & tn & tn \\
KK\% & $15,22 \%$ & $19,73 \%$ & $19,73 \%$ & $21,52 \%$ \\
\hline
\end{tabular}

Keterangan: Angka-angka pada kolom yang sama, diikuti dengan huruf yang sama berarti tidak berbeda nyata pada taraf uji BNT 0,05.

Pada Tabel 1, menunjukkan bahwa aplikasi pupuk organik cair sirih dan gamal (Sirgam Plus) terhadap pertumbuhan tinggi tanaman terung ungu pada umur 14 HST P0 berbeda nyata dengan P3 tapi P1 dan P2 tidak berbeda nyata. Hal ini berlaku juga pada umur 21

Diterbitkan Oleh,

HST P0 berbeda nyata dengan P3 tetapi tidak beda nyata dengan P1 dan P2. Pada umur 28 HST dan 35 HST semua perlakuan tidak memberikan pengaruh yang nyata pada pertumbuhan tinggi tanaman terung ungu. 
Perlakuan pupuk organik cair dengan dosis yang berbeda menunjukkan pertumbuhan tanaman yang juga berbeda. Namun dari hasil analisis keragaman menunjukkan bahwa, pemberian pupuk organik cair sirih dan gamal (Sirgam Plus) hanya berpengaruh nyata pada umur 14 HST, tetapi pada umur 21 HST, 28 HST, dan 35 HST tidak berpengaruh nyata. Hal ini disebabkan oleh proses penyerapan unsur hara oleh tanaman yang kurang maksimal karena kurangnya air pada media tanam. Menurut Harwati (2007), penyerapan unsur hara oleh tanaman sangat berpengaruh terhadap ketersediaan air pada tanah. Air berperan penting dalam pelarutan hara serta translokasi hara dan hasil fotosintesis ke seluruh bagian sel tanaman. Faktor lainnya yang dapat mempengaruhi pertumbuhan tanaman terung adalah faktor lingkungan, salah satunya adalah faktor tanah. Jenis tanah yang digunakan pada kaji widya ini adalah tanah (latosol), jenis tanah ini berwarna merah hingga kuning yang bersifat tidak terlalu subur karena kandungan zat besi dan aluminium yang tinggi sehingga dapat menghambat pertumbuhan tanaman terung ungu.

\section{Jumlah Daun}

Hasil pengamatan pada aplikasi pupuk organik cair sirih dan gamal (Sirgam Plus) terhadap pertumbuhan dan produksi tanaman terung ungu yang telah dilaksanakan dengan parameter pengamatan yaitu jumlah daun, yang dilakukan pada umur 14 sampai $35 \mathrm{HST}$, dapat di lihat pada tabel 2

Tabel 2. Jumlah daun tanaman terung ungu pada aplikasi pupuk organik cair (Sirgam Plus) pada umur 14, $21,28,35$ HST.

\begin{tabular}{ccccc}
\hline \multirow{2}{*}{ Perlakuan } & \multicolumn{4}{c}{ Minggu $(\mathrm{cm})$} \\
\cline { 2 - 5 } & 14 HST & 21 HST & 28 HST & 35 HST \\
\hline P0 & 5,17 & $6,67^{\mathrm{a}}$ & 9,92 & 22,33 \\
P1 & 5,25 & $8,92^{\mathrm{ab}}$ & 17,50 & 37,17 \\
P2 & 5,33 & $7,50^{\mathrm{ab}}$ & 11,75 & 23,67 \\
P3 & 5,75 & $11,42^{\mathrm{b}}$ & 17,33 & 37,83 \\
BNT & tn & tn & tn & tn \\
KK\% & $352,02 \%$ & $23,75 \%$ & $48,33 \%$ & $59,14 \%$ \\
\hline
\end{tabular}

Berdasarkan Tabel 2, aplikasi berbagai dosis pupuk organik cair sirih dan gamal (Sirgam Plus) terhadap jumlah daun tanaman terung ungu pada umur 14, 28, dan 35 HST P0 tidak berbeda nyata dengan P1, P2, dan P3. Pada umur 21 HST, $\mathrm{P} 0$ berbeda nyata dengan $\mathrm{P} 3$ tapi P1 dan P2 tidak berbeda nyata dengan P0 dan P3. Pertumbuhan jumlah daun tanaman terung ungu pada umur 14 sampai 35 HST. Perlakuan dengan menggunakan pupuk organik cair sirih dan gamal (Sirgam Plus) tidak menunjukkan pegaruh yang nyata pada setiap perlakuan umur 14, 21, 28, dan 35 HST. Hal ini disebabkan karna kurang terserapnya unsur hara $\mathrm{N}$ ke dalam tanah sehingga pertumbuhan jumlah daun pada terung ungu kurang maksimal. Menurut Lakintan (2001), bahwa unsur hara yang paling berpengaruh terhadap pertumbuhan dan perkembangan daun adalah unsur N. Kadar unsur N yang banyak umumnya menghasilkan daun yang lebih bayak dan lebih besar.

\section{Jumlah Cabang}

Hasil pengamatan pada aplikasi pupuk organik cair sirih dan gamal (Sirgam Plus) terhadap pertumbuhan dan produksi tanaman terung ungu yang telah dilaksanakan dengan parameter pengamatan yaitu jumlah cabang, yang dilakukan pada umur 28 dan 35 HST, dapat di lihat pada tabel 3. 
Tabel 3. Jumlah cabang tanaman terung ungu pada aplikasi pupuk organik cair (Sirgam Plus) pada umur 28 dan 35 HST

\begin{tabular}{ccc}
\hline \multirow{2}{*}{ Perlakuan } & \multicolumn{2}{c}{ Minggu $(\mathrm{cm})$} \\
\cline { 2 - 3 } & 28 HST & 35 HST \\
\hline P0 & 2,00 & 6,69 \\
P1 & 4,11 & 11,72 \\
P2 & 3,22 & 7,25 \\
P3 & 5,33 & 11,08 \\
BNT & tn & tn \\
KK\% & $64,03 \%$ & $53,31 \%$ \\
\hline
\end{tabular}

Berdasarkan Tabel 3, aplikasi berbagai dosis pupuk organik cair sirih dan gamal (Sirgam Plus) terhadap jumlah cabang tanaman terung ungu pada umur 28 dan 35 HST P0 tidak berbeda nyata dengan P1, P2, dan P3. Pertumbuhan jumlah cabang tanaman terung ungu pada umur 28 dan 35 HST.

Perlakuan dengan menggunakan pupuk organik cair sirih dan gamal (Sirgam Plus) tidak menunjukkan pegaruh yang nyata pada setiap perlakuan umur 28 dan 35 HST. Hal ini karena adanya pengaruh dari pertumbuhan tinggi tanaman yang juga menunjukkan hasil yang berbeda tidak nyata terhadap semua perlakuan.
Menurut Harjodwigeno (2007), pertumbuhan tinggi tanaman turut mempengaruhi jumlah cabang karena batang merupakan tempat melekat dan tumbuhnya cabang. Tanaman yang cukup tinggi memungkingkan tumbuhnya cabang yang lebih banyak.

\section{Berat Basah}

Hasil pengamatan pada aplikasi pupuk organik cair sirih dan gamal (Sirgam Plus) terhadap pertumbuhan dan produksi tanaman terung ungu yang telah dilaksanakan dengan parameter pengamatan yaitu berat basah, yang dilakukan pada umur 50 HST, dapat di lihat pada tabel 4.

Tabel 4. Berat basah tanaman terung ungu

\begin{tabular}{cc}
\hline Perlakuan & Berat Basah $(\mathrm{g})$ \\
\hline P0 & $181,08^{\mathrm{a}}$ \\
P1 & $230,75^{\mathrm{c}}$ \\
P2 & $191,67^{\mathrm{ab}}$ \\
P3 & $245,75^{\mathrm{c}}$ \\
BNT & 35,93 \\
KK\% & $8,59 \%$ \\
\hline
\end{tabular}

Keterangan: Angka-angka pada kolom yang sama, diikuti dengan huruf yang sama berarti tidak berbeda nyata pada taraf uji BNT 0,05.

Berdasarkan tabel 4, hasil penimbangan berat basah tanaman terung ungu setelah panen pada perlakuan $\mathrm{P} 0$ berbeda nyata dengan $\mathrm{P} 1$ dan P3 tetapi tidak berbeda nyata denga P2. Perlakuan dengan menggunakan pupuk organik cair sirih dan gamal (Sirgam Plus) berpengaruh nyata terhadap berat buah per tanaman. Hasil analisis pada tabel 11 menunjukkan bahwa pemberian pupuk organik cair sirih dan gamal (Sirgam Plus) pada perlakuan P3 (900 ml/ha) memberikan hasil Diterbitkan Oleh, seberat $245,75 \mathrm{~g}$ yang berbeda nyata terhadap $\mathrm{P} 0$ tetapi tidak berbeda nyata dengan perlakuan P1 (300 $\mathrm{ml} / \mathrm{ha})$. Hal ini diduga karena adanya kandungan unsur P didalam POC yang berperan penting dalam proses metabolisme tanaman.

Menurut Lakitan (2001), unsur P berfungsi untuk mengubah karbohidrat seperti dalam perubahan tepung menjadi gula. Hasil perubahan karbohidrat tersebut akan berperan dalam pembentukan baik ukuran buah maupun

Unit Penelitian dan Pengabdian Masyarakat, Politeknik Pembangunan Pertanian Gowa

http://ejournal.polbangtan-gowa.ac.id 
DOI:

berat buah, jika ketersediaan unsur $\mathrm{P}$ dalam tanah tersedia bagi tanaman maka akan menambah ukuran dan berat hasil basah.

\section{KESIMPULAN}

1. Berdasarkan hasil analisis sidik ragam aplikasi pupuk organik cair sirih dan gamal (Sirgam Plus) tidak berpengaruh terhadap pertumbuhan tinggi tanaman, jumlah daun dan jumlah cabang tanaman terung ungu (Solanum melongena L.) namun berpengaruh baik terhadap hasil atau berat buah sebesar 1,6 Ton/Ha atau 245,75 g.

2. Petani merespons terhadap materi yang disampaikan yakni pada aspek pengetahuan responden meningkat $31,6 \%$, sikap $28,5 \%$, dan keterampilan sebesar $44 \%$.

\section{DAFTAR PUSTAKA}

Busroni, M.P, Ir Rostian Nafery, M.P,

$\begin{array}{lrr}\text { AyuPuspita } & \text { Sari. } & \text { 2018. } \\ \text { ResponTanaman } & \text { Terong } & \text { Ungu } \\ \text { (Solanum } & \text { Melongena } & \text { L.) } \\ \text { AkibatPemberian } & \text { Pupuk } & \text { Organik } \\ \text { Cair Mol } & \text { Daun } & \text { Gamal } \\ \text { (GliricidiaSepium } & \text { (Jacq.) } \\ \text { KunthEx } & \text { Walp.) } & \text { Terhadap } \\ \text { Pertumbuhan } & \text { Dan } & \text { Hasil. } \\ \text { Fakultas Pertanian } & \text { Universitas } \\ \text { Tridinanti Palembang. } & \text { Jurnal } \\ \text { Triagro.Vol3No.1. } & \end{array}$

Harjodwgeno, S. 2007. Ilmu Tanah. Akademika Pressindo. Jakarta.

Harwati, T. 2007. Pengaruh Kekurangan Air (Water Deficit) terhadap
Pertumbuhandan Perkembangan

TanamanTembakau. Jurnal Inovasi Pertanian.(Online)http://www.univt ridinanti.ac.id. Diakses pada tanggal 28 Juli 2021.

Jusuf, L., A.M Mulyati dan A.H Sanaba. 2007. Pengaruh Dosis Pupuk Organik Padat Daun Gamal terhadap Tanaman Sawi. Gowa: Sekolah Tinggi Penyuluhan Pertanian (STPP). Jurnal Agrisistem. 3:27-31.

Karim Fahri, Nikmah Musa, Fitriah S,dan Jamin. 2013. Respon Pertumbuhan Produksi Tanaman Terong (Solanum Melongena L) Terhadap Perlakuan Phonska.

Lakitan, B. 2001. Dasar-Dasar Fisiologi Tumbuhan. Penebar Swadaya. Jakarta.

Melda Pratiwi. 2017. Potensi Daun Sirih (Piper Betle L) Sebagai Pupuk Organic Cair Dengan Metode Ekstrak Tanaman Terfermentasi Dan Aplikasinya Pada Tanaman Tomat (Solanum Lycopersicum M.). Skripsi Fakultas Matematika Dan Ilmu Pengetahuan Alam. Universitas Andalas. (Online) http://scholar. unand.ac.id/27832/ Diakses pada tanggal 21 Maret 2021.

Padmowihardjo, 2002. Metode Penyuluhan Pertanian. Universitas Terbuk Jakarta

Sahid, O.T., R.H. Murti dan S. Trisnowati. 2014. Hasil Mutu Enam Galur Terung (Solanum melongena L). 